\title{
The benzodiazepines use and psychological intervention in a Porto health center
}

\author{
Benzodiazepinas e o acompanhamento psicológico dos utentes de um centro de saúde da \\ cidade do Porto
}

\author{
Joana Regalado${ }^{1}$, José Carlos Rocha ${ }^{6}$, Ivone Duarte ${ }^{3}$, Catarina Canário ${ }^{5}$, Inês Sampaio ${ }^{4}$, Sílvia Marina ${ }^{3}$, \\ Miguel Ricou ${ }^{3}$ \\ ${ }^{1}$ Portucalense University \\ ${ }^{2}$ Higher Institute of Health Sciences - North \\ ${ }^{3}$ Department of Community Medicine, Information and Health Decision Sciences of the Faculty of Medicine of the \\ University of Porto \\ ${ }^{4}$ Trás-os-Montes and Alto Douro University \\ ${ }^{5}$ Faculdade de Psicologia e Ciências da Educação da Universidade do Porto, Rua Alfredo Allen, 4200-135 Porto \\ ${ }^{6}$ IINFACTS, CESPU, Rua Paço 5, 4560-462 Penafiel \\ e-mail:mricou@med.up.pt
}

\begin{abstract}
The misuse of benzodiazepines is a well know public health problem. For this reason, it is more and more relevant to monitor misuse and try to implement solutions. We aim to understand the use of benzodiazepines in a health center population in the city of Porto, as well the connections with present, past and future psychological intervention.

We have built a questionnaire to assess usage of both benzodiazepines and psychological services. Our sample population included individuals older than 18 years who picked up our questionnaire in health center waiting rooms. A total of 352 participants, 258 females and 92 males, answered the questionnaire.

Results points to an excessive use of benzodiazepines, especially in older persons, divorced or widowed, and females. We found a significant association between the current interest in receiving psychological intervention and the use of benzodiazepines. In the same way, the participants who have received psychological intervention use benzodiazepines less in comparison to the participants who are still receiving psychological intervention. In conclusion, there is an abuse of benzodiazepines in this health center, and few access to psychological intervention that may have good results reducing benzodiazepines abuse.
\end{abstract}

Keywords: psychological intervention; benzodiazepines; primary health care

\section{Resumo}

O uso inadequado de benzodiazepinas é um problema de saúde pública bem conhecido e, por isso, é particularmente relevante a sua monitorização e a implementação de soluções adequadas. Pretendemos conhecer a realidade dos utentes de um Centro de Saúde na Cidade do Porto relativamente ao consumo de benzodiazepinas, bem como a sua relação com o acompanhamento psicológico passado, atual ou futuro por parte dos mesmos.

Foi construído um inquérito por questionário. Foi aplicado a indivíduos com mais de 18 anos nas salas de espera do Centro de Saúde. Responderam ao questionário 352 participantes, dos quais 258 mulheres e 92 homens.

Os resultados obtidos apontam para um consumo excessivo de benzodiazepinas com predominância nas pessoas com mais idade, divorciadas ou viúvas, e do sexo feminino. Verificou-se uma associação significativa entre o interesse atual em ter acompanhamento psicológico e o consumo de benzodiazepinas. Os utentes que beneficiaram de acompanhamento psicológico consomem menos benzodiazepinas, quando comparados com os que ainda estão em acompanhamento.

Em conclusão, pode salientar-se que existe um consumo desproporcionado de benzodiazepinas nos cuidados de saúde primários, havendo um acesso reduzido à intervenção psicológica que pode apresentar bons resultados ao nível da redução da utilização destes fármacos.

Palavras-chave: acompanhamento psicológico; benzodiazepinas; cuidados de saúde primários 


\section{Introduction}

It is agreed that benzodiazepines cause dependence and tolerance with prolonged use (1). In addition, this type of drug use causes side effects such as daytime sleepiness, reduced cognitive functions, memory loss and imbalance (2). Benzodiazepines are considered safe and effective for the designations for which they are approved, and during appropriate treatment periods, i.e. less than three months $(3,4)$. Their use in primary health care often seems to be higher than recommended (5), so it is important evaluate this potential reality. Due to the lack of knowledge about the risk/benefit relationship of pharmacological treatment and many health care systems which are incapable of responding to different needs $(6,3)$, benzodiazepines are often prescribed in generalized anxiety disorder (7), stress, insomnia, panic disorder, in certain phobias and psychosomatic complaints such as tension headache and dermatitis. Benzodiazepines are also used in muscular contractions and epilepsy (3).

The involvement of the patient to understand and choose the type of intervention, considering non-pharmacological approaches, should be considered (8). However, the World Health Report (9) indicates that about one in two patients affirm that their doctor rarely or never asks their opinion about the proposed treatment. An awareness of the medical prescribing guidelines and providing clear information to the patients appears to be important to promote proper use (10). Lack of knowledge may reflect poor adhesion to other interventions, leading to a tendency to self-medication independent of recommendations, increasing this way the probability of dependency (1). In fact, the circumstances in which people use these pharmacological substances seem to serve an important role for the abusive use (1).

According to the National Program for Mental Health $(11,12)$, in 2012 there was an increase of $6 \%$ in the consumption of anxiolytic and sedative hypnotic drugs in Portugal when compared to the year 2000. In comparison with others European countries, Portugal ranks second in the consumption of psychopharmacological drugs (13) and the first in the use of benzodiazepines (14).

In times of crisis, it is expected that the problems associated with psychological disorders will increase significantly. Psychology can offer a significant contribution to the reduction of healthcare expenditures, as well as to the progressive improvement of the health status of the population (15). In research conducted by Harkness and Bower (16), the inclusion of mental health professionals in primary health care was found to lead

\section{Introdução}

É consensual que as benzodiazepinas causam dependência e tolerância com o uso prolongado (1). Ademais, este tipo de utilização provoca efeitos secundários, desde a simples sonolência diurna até à diminuição de funções cognitivas, perda de memória e desequilíbrio (2). As benzodiazepinas são consideradas seguras e efetivas nas designações para as quais estão aprovadas e por períodos adequados, ou seja, inferiores a três meses (3, 4). A sua utilização nos cuidados de saúde primários parece ser, muitas vezes, superior ao aconselhado (5), pelo que importa avaliar essa mesma realidade.

Decorrente do desconhecimento da relação risco/benefício do tratamento farmacológico e de um sistema de saúde incapaz de dar resposta às diferentes solicitações $(6,3)$ as benzodiazepinas são habitualmente prescritas na perturbação de ansiedade generalizada (7), nas queixas subjetivas de nervosismo, ansiedade, stress e insónia, na perturbação de pânico, em certas fobias e queixas psicossomáticas como a cefaleia de tensão e a dermatite. Além disso, são também utilizadas nas contraturas musculares e na epilepsia (3).

O envolvimento do paciente na compreensão e escolha do tipo de intervenção, considerando abordagens não farmacológicas, deve ser considerado (8). Contudo, o Relatório Mundial de Saúde (9) salienta que cerca de um em cada dois doentes afirma que o médico raramente, ou mesmo nunca, lhes pergunta qual é a opinião acerca do tratamento que lhes é proposto. A consciencialização da prescrição médica, bem como o fornecimento das informações claras aos doentes parece ser importante para promover uma utilização adequada (10). O desconhecimento pode fazer refletir uma má adesão a outro tipo de intervenções, levando a uma tendência a automedicação independente das recomendações, aumentando a probabilidade de se promoverem estados de dependência (1). Aliás, as circunstâncias em que as pessoas utilizam este tipo de fármacos parecem desempenhar um papel importante na predisposição para o uso abusivo (1).

No ano 2012, constatou-se um acréscimo de $6 \%$ no consumo de ansiolíticos e hipnóticos sedativos relativamente ao ano 2000, dados estes, confirmados pelo Programa Nacional para a Saúde Mental $(11,12)$. Face aos restantes países da europa, Portugal ocupa o segundo lugar no que diz respeito ao consumo de psicofármacos (13) e o primeiro a consumir mais benzodiazepinas (14).

Em momentos de crise é de esperar que aumentem significativamente os problemas associados a perturbações psicológicas. A Psicologia poderá ter uma contribuição 
to a decreased number of general and family medicine consultations and lower prescribing of psychopharmacological drugs. Psychology in primary health care can, in certain way, minimize costs and increase patient well-being (17).

Taking the above into account, we intend to characterize the consumption of benzodiazepines and their association with psychological consultations in a primary health care institution in Portugal.

\section{Material and methods}

\section{Participants}

The sample was obtained through the accidental sampling method (18). This study's sample is composed of 352 participants with an average age of 47.81 years (SD $=16.58$ ) (Table 1). A majority of the sample was female (73.7\%). The data collection took place from October 2012 to January 2013. Participants responded to a questionnaire elaborated for this study in the waiting rooms of the health center.

The questionnaire that was used included multiplechoice questions divided into five parts. The first part included personal data; the second was composed of two groups of closed questions that aim to evaluate the current and past patterns of benzodiazepine consumption and the underlying reasons; the third part concerned the prescription of benzodiazepines; the fourth part was comprised three groups of closed questions with the goal of exploring the person's current, past or future participation in a process of psychological intervention. Finally, the last part was composed of a closed group of questions and evaluated the current interest in having psychological intervention. At the end of the questionnaire, a listing with the commercial name of all Benzodiazepines (BZs) in the Portuguese pharmacological market was included.

\section{Statistical procedures}

Data analysis was undertaken using the PASW v.18 software. The association between gender, age, marital status, and current consumption of benzodiazepine was evaluated using the Chi-square test. The two-proportion z-test evaluated the association between psychological significativa tanto para a redução da despesa da saúde, como para a melhoria progressiva do estado de saúde da população (15). Numa investigação de Harkness e Bower (16) foi constatado que a presença de profissionais de saúde mental nos cuidados de saúde primários leva a uma diminuição do número de consultas de medicina geral e familiar, bem como à quantidade de psicofármacos prescritos. A psicologia nos cuidados de saúde primários poderá então ser de certa forma rentável, minimizando os custos e aumentando o bem-estar dos utentes (17).

Tendo em consideração o acima descrito pretende-se caraterizar o consumo de benzodiazepinas, bem como a sua associação ao recurso à consulta de psicologia numa instituição dedicada aos cuidados de saúde primários em Portugal.

\section{Material e méodos}

\section{Participantes}

A amostra foi obtida através do método de amostragem acidental (18). É constituída por 352 participantes com uma média de idade de 47.81 anos ( $\mathrm{DP}=16.58)$ (Tabela 1) sendo a maioria do sexo feminino $(73.7 \%)$. Os dados foram recolhidos junto dos utentes que aguardavam consulta nas salas de espera do Centro de Saúde entre outubro de 2012 e janeiro de 2013, através de um questionário construído para o efeito.

O questionário consistiu em questões de escolha múltipla dividido em cinco partes. A primeira engloba dados pessoais; a segunda é constituída por dois grupos de questões fechadas que pretendem avaliar os padrões atuais e passados do consumo de benzodiazepinas, bem como os motivos a eles subjacentes; a terceira parte diz respeito à prescrição de benzodiazepinas; a quarta parte, é composta por três grupos de questões fechadas com o objetivo de explorar a participação atual, passada ou futura da pessoa num processo de Intervenção Psicológica. Finalmente, a última parte com um grupo fechado de questões, avalia o interesse atual em ter acompanhamento psicológico. No fim do questionário foi incluída uma listagem com o nome comercial de todas as Benzodiazepinas (BZs) existentes no mercado farmacológico português.

\section{Procedimentos estatísticos}

O procedimento estatístico para a obtenção dos resultados utilizou o programa PASW v.18. A associação entre o sexo, a idade, o estado civil e os consumos atuais de benzodiazepinas foi avaliada através da medida de associação Qui-quadrado. Por sua vez, a associação 
intervention and benzodiazepine consumption. All the statistical assumptions that legitimize the use of the aforementioned analyzes were fullfilled.

\section{Study Procedures}

Approval for the study was requested and promptly granted by the direction of the health care center. The participants' informed consent was obtained and was ensured the confidentiality and privacy of the data. After accepting the voluntary participation, a copy of the questionnaire was provided to each participant. Researchers were present during the self-administration to clarify any doubts.

The study was approved by the ethics committee of the health care center. entre o acompanhamento psicológico e o consumo de benzodiazepinas foi avaliada através do two-proportion $z$-test.

Todos os pressupostos estatísticos que legitimam a utilização das análises supra-citadas foram verificados, encontrando-se cumpridos.

\section{Procedimentos do estudo}

A aprovação para a realização do estudo foi solicitada e prontamente concedida pela Direção do Centro de Saúde. Obteve-se o consentimento informado dos participantes garantindo-se a confidencialidade e privacidade dos dados. Após aceitarem a participação voluntária foi entregue a cada utente uma cópia do questionário e uma esferográfica. Os investigadores estiveram sempre presentes durante a autoadministração, afim de esclarecer qualquer dúvida que surgisse.

O estudo foi aprovado pela Comissão de Ética do Centro de Saúde.

Table 1/ Tabela 1 - Sociodemographic characterization of the sample/ Caraterização sociodemográfica da amostra

\begin{tabular}{|c|c|c|c|c|}
\hline & $n$ & $\%$ & $M$ & $S D$ \\
\hline \multicolumn{5}{|l|}{ Gender/ Género } \\
\hline Feminine/ & 258 & 73.7 & & \\
\hline Feminino & 92 & 26.3 & & \\
\hline \multicolumn{5}{|l|}{ Masculine/ } \\
\hline \multicolumn{5}{|l|}{ Masculino } \\
\hline Age/ Idade & & & 47.81 & 16.58 \\
\hline \multicolumn{5}{|l|}{ Marital Status/ } \\
\hline Estado Cívil & 79 & 22.4 & & \\
\hline Single/ Solteiro & 195 & 55.4 & & \\
\hline Married/ Casado & 42 & 11.9 & & \\
\hline Divorced/ & 36 & 10.2 & & \\
\hline \multicolumn{5}{|l|}{ Divorciado } \\
\hline \multicolumn{5}{|l|}{ Widower/ Viúvo } \\
\hline \multicolumn{5}{|l|}{ Education Level/ } \\
\hline Escolaridade & 2 & 0.6 & & \\
\hline None/ Nenhuma & 76 & 21.6 & & \\
\hline 4 years $/ 4^{\circ}$ ano & 38 & 10.8 & & \\
\hline 6 years $/ 6^{\circ}$ ano & 63 & 17.9 & & \\
\hline 9 years $/ 9^{\circ}$ ano & 75 & 21.3 & & \\
\hline 12 years/ $12^{\circ}$ ano & 61 & 17.3 & & \\
\hline Bachelors/ & 37 & 10.5 & & \\
\hline \multicolumn{5}{|l|}{ Bacharel } \\
\hline Others/ Outro & & & & \\
\hline
\end{tabular}




\section{Results}

A majority of participants $(n=164,56.2 \%)$ stated they had consumed benzodiazepines in the past and $36.2 \%$ $(n=125)$ consumed at the time of the evaluation. The main reasons for the benzodiazepine consumption indicated were anxiety $(\mathrm{n}=50,61.7 \%, \mathrm{n}=74,64.9 \%)$, depression ( $\mathrm{n}=36,42.9 \%, \mathrm{n}=56,49.1 \%)$, sleeping problems $(\mathrm{n}=30,37.5 \%, \mathrm{n}=52,49.1 \%)$ and excessive concern $(n=13,17.6 \%, n=164,25.3 \%)$.

Most prescriptions of benzodiazepines are made by the family doctor $(\mathrm{n}=98,67.1 \%)$ followed by psychiatrists $(\mathrm{n}=33,22.6 \%)$. Benzodiazepine consumption exceeded three months at the (present) time of the evaluation $(\mathrm{n}=62,54.4 \%)$ and in the past $(\mathrm{n}=96,56.5 \%)$.

The results indicate an association between current consumption and gender X2(1) $=15.53, \mathrm{p}<.001$, RR $=0.46$, IC95\%(0.29-0.72), age X2(1) = 14.16, p<.001, $\mathrm{RR}=0.59$, IC95\%(0.44-0.78) and marital status X2(3) $=10.24, \mathrm{p}<.05$. There was no association between current consumption and education level $\mathrm{X} 2(1)=0.18$, n.s., RR $=1.06$, IC95\%(0.80-1.41). Regarding gender, women ( $\mathrm{n}=107,42.0 \%)$ had a higher current consumption of benzodiazepines when compared to the men $(\mathrm{n}=$ $17,19.3 \%)$. Participants aged 50 years or older $(n=71$, $47.3 \%$ ) had higher current benzodiazepine consumption compared to the participants younger than 50 years $(\mathrm{n}=54,27.7 \%)$. Widowed participants $(\mathrm{n}=20,57.1 \%)$ and divorced $(\mathrm{n}=19,45.2 \%)$ had a higher prevalence of current benzodiazepine consumption than single (n $=23,30.3 \%)$ and married $(\mathrm{n}=63,32.8 \%)$ participants. Also evaluated was the existence of associations between the current consumption of benzodiazepines and the current psychological intervention $(Z=3.77, p<.001)$, between current consumption of benzodiazepines and actual vs past psychological intervention $(Z=1.97, p<.05)$, and between current consumption of benzodiazepines and the interest in having psychological intervention $\mathrm{X} 2(1)=25.31, \mathrm{p}<.001, \mathrm{RR}=2.78, \mathrm{IC} 95 \%(1.85-4.17)$ (Table 2). The findings demonstrate that the majority of participants who consume benzodiazepines currently do not have psychological intervention, and most participants who had psychological intervention on past do not consume benzodiazepines currently. Additionally, the majority of participants who are in psychological intervention consume benzodiazepines. Finally, the results indicate that participants without psychological intervention and with current benzodiazepine consumption $(\mathrm{n}=38,43.7 \%)$ are more interested in having psychological intervention than participants without psychological intervention and without current benzodiazepine consumption $(\mathrm{n}=30,15.7 \%)$.

\section{Resultados}

A maioria dos participantes $(\mathrm{n}=164,56.2 \%)$ afirma ter consumido benzodiazepinas no passado, e $36.2 \%$ ( $\mathrm{n}=$ 125) consome no momento da avaliação. Os principais motivos apontados para o consumo de benzodiazepinas são a ansiedade $(\mathrm{n}=50,61.7 \%, \mathrm{n}=74,64.9 \%)$, a depressão ( $\mathrm{n}=36,42.9 \%, \mathrm{n}=56,49.1 \%)$, os problemas com o sono $(\mathrm{n}=30,37.5 \%, \mathrm{n}=52,49.1 \%)$ e a preocupação excessiva $(n=13,17.6 \%, n=164,25.3 \%)$.

O principal prescritor das benzodiazepinas é o médico de família ( $\mathrm{n}=98,67.1 \%$ ) seguido do psiquiatra (n $=33,22.6 \%$ ). Os consumos prolongam-se por mais de três meses, tanto no momento atual $(\mathrm{n}=62,54.4 \%)$ como no passado $(\mathrm{n}=96,56.5 \%)$.

Os resultados indicam uma associação entre o consumo atual e o género, $\mathrm{X} 2(1)=15.53, \mathrm{p}<.001, \mathrm{RR}=0.46$, IC95\%(0.29-0.72), o consumo atual e a idade, X2(1) $=14.16, \mathrm{p}<.001, \mathrm{RR}=0.59, \mathrm{IC} 95 \%(0.44-0.78)$, e o consumo atual e o estado civil, X2(3) $=10.24, \mathrm{p}<.05$, mas não entre o consumo atual e a escolaridade X2(1) $=0.18$, n.s., RR $=1.06$, IC95\%(0.80-1.41). Quanto ao género, as mulheres $(\mathrm{n}=107,42.0 \%)$ apresentam maior prevalência de consumo atual de benzodiazepinas face aos homens $(\mathrm{n}=17,19.3 \%)$. Os participantes com idade igual ou superior a 50 anos $(\mathrm{n}=71,47.3 \%)$ apresentam maior prevalência de consumo atual de benzodiazepinas comparativamente aos participantes com idade inferior a 50 anos $(\mathrm{n}=54,27.7 \%)$. Os participantes viúvos $(\mathrm{n}=20,57.1 \%)$ e divorciados $(\mathrm{n}=19,45.2 \%)$ apresentam maior prevalência de consumo atual de benzodiazepinas do que os participantes solteiros ( $\mathrm{n}=$ $23,30.3 \%)$ e casados $(\mathrm{n}=63,32.8 \%)$.

Verificou-se ainda a existência de associações entre o consumo atual de benzodiazepinas e o acompanhamento psicológico atual, $\mathrm{Z}=3.77, \mathrm{p}<.001$, entre o consumo atual de benzodiazepinas e o acompanhamento psicológico atual vs. passado, $\mathrm{Z}=1.97, \mathrm{p}<.05$, e o consumo atual de benzodiazepinas e o interesse em ter acompanhamento psicológico, $\mathrm{X} 2(1)=25.31, \mathrm{p}<.001, \mathrm{RR}=$ 2.78, IC95\%(1.85-4.17), tal como apresentado na Tabela 2. Os resultados apontam que a maioria dos participantes que consome benzodiazepinas atualmente não tem acompanhamento psicológico, e a maioria dos participantes que teve acompanhamento psicológico passado não consome benzodiazepinas atualmente. Ainda, a maioria dos participantes que tem acompanhamento psicológico atualmente consome benzodiazepinas. Por último, os resultados demonstram que os participantes sem acompanhamento psicológico e com consumo atual de benzodiazepinas $(\mathrm{n}=38,43.7 \%)$ apresentam maior interesse em ter acompanhamento psicológico do 
Table 2/ Tabela 2 - Frequencies between actual benzodiazepines consumption and actual psychological intervention with Chi-square and $Z$ test/ Frequências entre consumo atual de Benzodiazepinas e acompanhamento psicológico com Qui-quadrado e Z teste

\begin{tabular}{|c|c|c|c|c|}
\hline & \multicolumn{4}{|c|}{$\begin{array}{l}\text { Actual benzodiazepines consumption/ } \\
\text { Consumo atual de Benzodiazepinas }\end{array}$} \\
\hline & \multicolumn{2}{|c|}{ Yes/ Sim } & \multicolumn{2}{|c|}{ No/ Não } \\
\hline & $n$ & $\%$ & $n$ & $\%$ \\
\hline \multicolumn{5}{|l|}{$\begin{array}{l}\text { Actual psychological } \\
\text { intervention/ Acompanhamento } \\
\text { psicológico atual }\end{array}$} \\
\hline Yes/ Sim & 29 & 60.4 & 19 & 39.6 \\
\hline No/ Não & 94 & 32.2 & 198 & 67.8 \\
\hline$Z$ & $3.77 * * *$ & & & \\
\hline $\begin{array}{l}\text { Actual psychological } \\
\text { intervention/ Acompanhamento } \\
\text { psicológico atual }\end{array}$ & 29 & 60.4 & 19 & 39.6 \\
\hline $\begin{array}{l}\text { Past psychological intervention/ } \\
\text { Acompanhamento psicológico } \\
\text { passado }\end{array}$ & 18 & 40.3 & 27 & 59.3 \\
\hline$Z$ & & & & \\
\hline
\end{tabular}

\section{Discussion}

Benzodiazepines have been reported to be used at levels considered excessive $(3,19)$, which seems to be confirmed by the results of this study. In fact more than $55 \%$ of participants in this study claim having consumed benzodiazepines. In addition, the time of use for these pharmacological substances has exceeded the recommended period of use up to a maximum of three months $(20,21)$. About $60 \%$ of participants report having taken benzodiazepines for periods of more than three months and $32 \%$ maintained this use for more than one year. The reasons mentioned for consumption are in agreement with those indicated in the literature, such as, sleeping problems, anxiety $(22,23)$, and depressive symptomatology often associated with anxiety $(24,25)$. In line with other studies (26), also in this study, physicians are the main prescribers of these drugs, specifically specialists in general and family medicine $(67.1 \%)$, followed by psychiatrists with $22.6 \%$. About $90 \%$ of benzodiazepine consumers start using in the context of a physician-patient relationship, however, a large percentage of patients consume for more time than recommended. Thus, questions about correct use can be raised, or even about the pertinence of the same. Improper uses can led to undesirable consequences, in particular, the dependence and chronic use of these drugs. In fact, although family doctors do not seem to believe that benzodiaze- que os participantes sem acompanhamento psicológico e sem consumo atual de benzodiazepinas $(n=30$, $15.7 \%)$.

\section{Discussão}

A utilização de benzodiazepinas parece atingir níveis considerados excessivos $(3,19)$, o que os resultados obtidos neste estudo parecem confirmar. De facto mais de $55 \%$ dos participantes neste estudo afirmaram ter consumido benzodiazepinas. Acresce que o tempo de utilização das mesmas ultrapassada o período aconselhável indicado, no máximo cerca de 3 meses $(20,21)$. Cerca de $60 \%$ dos participantes afirma tê-lo feito por períodos superiores e $32 \%$ mantém este consumo há mais de 1 ano.

Os motivos apontados para o consumo são coincidentes com aqueles que a literatura considera como indicados para a prescrição de benzodiazepinas, ou seja, os problemas de sono e a sintomatologia ansiosa (22, 23), ao que acresce a sintomatologia depressiva, também ela muitas vezes associada à ansiedade $(24,25)$. Segundo os resultados deste estudo os médicos são os principais prescritores destes fármacos, com os especialistas de medicina geral e familiar à cabeça com $67.1 \%$ das prescrições, seguidos dos psiquiatras com $22.6 \%$, o que não difere muito de outros estudos (26). 
pines can be an effective solution to some complaints, they will continue to prescribe them due to a shortage of other valid pharmacological options with immediate impact on symptoms (27). Likewise, it may be difficult for the physician to refuse the patient request for renewal of the medication. The difficulty in denying patients' requests for medication renewal may be due in part, to the preservation of a good relationship with the patient. Belonging to the female gender, being over 50 years old and being widowed or divorced seem to be factors associated with the consumption of benzodiazepines, although this does not occur for the consumption during excessive time periods. Age can be a strong predictor of the long-term consumption of benzodiazepines (28), however, this was not observed in this study, although a tendency can be seen in this sense. All other factors analyzed, sex, marital status, and education level (29, $30,31,32,33)$ are indicated as risk factors for benzodiazepine consumption, but not for prolonged use. These results of this study are in agreement with the generality of other studies found, except the education level, which does not present significant differences.

Psychological intervention can contribute in some way for the reduction of benzodiazepine use. Several studies assume that psychological intervention is very effective, as pharmacological treatment at short-term, however it is more effective with long-term treatment (17, 34). In fact, the results of this study indicate that participants who have psychological intervention consume more benzodiazepines than those do not have psychological intervention, which will be understandable. In fact, in a research study conducted by Ricou et al. (35) it was verified that the majority of the patients, about $90 \%$, were referred for the psychological consultation by the family doctor. Therefore, it is expected that these patients are more likely to use benzodiazepines. However, it is interesting to observe that about $60 \%$ of individuals who have completed the psychological intervention process do not consume benzodiazepines, which contrasts with the approximately $40 \%$ who are in psychological intervention process. Further longitudinal research is needed to confirm if psychological intervention contributes to reduce benzodiazepine use. But, it seems to be an interesting indicator that participants who have completed psychological intervention process have almost half of the probability to consume benzodiazepines compared to those who are still in psychological intervention. Additionally, psychological intervention seems to promote a reduction in pharmacological substances consumption in general $(17,36)$ and consequently, seems to decrease the number of general and family medicine consultations, minimize treatment costs and increase patient well-being (17). Another
Apesar de cerca de 90\% dos utilizadores de benzodiazepinas iniciarem o consumo no contexto de uma relação médico-doente, uma grande parte deles acaba por incorrer em utilizações consideradas excessivas no que diz respeito ao tempo recomendado para o tratamento, o que terá que levantar questões sobre a sua correta utilização ou mesmo sobre a pertinência da mesma. Será mais provável que utilizações inadequadas resultem em consequências não desejadas, nomeadamente na criação de processos de dependência e utilização crónica destes fármacos. Na verdade, apesar de os médicos de família parecerem não acreditar que as benzodiazepinas possam constituir-se, muitas vezes, como uma solução efetiva para algumas queixas, continuarão a prescrevê-las devido à escassez de outras opções farmacológicas válidas com impacto imediato nos sintomas (27). Do mesmo modo, pode ser possível que lhes seja por vezes difícil recusar ao utente o pedido de renovação da medicação. Independentemente de o médico ser um profissional autónomo, a verdade é que por vezes, provavelmente com vista à preservação de uma boa relação médico-doente, poderá ter dificuldades em recusar os pedidos dos utentes na renovação da medicação.

Pertencer ao sexo feminino, ter mais de 50 anos e ser viúvo ou divorciado parecem ser fatores associados à utilização de benzodiazepinas, ainda que tal não se verifique para a utilização por tempo excessivo. A idade será um forte preditor do consumo de longo termo de benzodiazepinas (28) o que de facto não acontece neste estudo, ainda que se possa descortinar uma tendência nesse sentido. Todos os outros fatores analisados, sexo, estado civil e escolaridade $(29,30,31,32,33)$ são indicados como fatores de risco para o consumo de benzodiazepinas, ainda que não para tempos de utilização prolongados. Os resultados obtidos neste estudo vão no mesmo sentido, exceto ao nível da escolaridade, que neste caso não apresenta grandes diferenças. Ainda assim, não será exagerado afirmar que as características desta amostra estarão de acordo com a generalidade dos outros estudos encontrados.

A intervenção psicológica pode contribuir de alguma forma para a diminuição do consumo de benzodiazepinas. Vários estudos indicam que a intervenção psicológica será pelo menos tão eficaz como o tratamento farmacológico a curto prazo, apresentando efeitos mais eficazes a longo prazo $(17,34)$. Na verdade, os resultados deste estudo indicam que os participantes que beneficiam de acompanhamento psicológico consomem mais benzodiazepinas do que aqueles que não o fazem, o que será compreensível. De facto, e num estudo levado a cabo por Ricou et al. (35) verificou-se que a maioria dos utentes, cerca de $90 \%$, eram encaminhados para a consulta de psicologia pelo médico de família. Esse 
interesting finding in this study is that a large part of benzodiazepine users express desire to have psychological intervention. These results may indicate some dissatisfaction with the results of the pharmacological intervention separate from psychological intervention. In this line, some literature (37) indicates that separate pharmacotherapy will provide less effective results than when combined with psychological intervention. It may also indicate high levels of motivation to initiate a process of this kind, favoring psychological intervention (38). At the same time, this result can indicate the existence of clear psychological intervention needs, perhaps due to the reduced offer of psychological services (39). Benzodiazepines are a group of anxiolytic drugs commonly used in the treatment of anxiety and insomnia. Although the recommendations are for short-time use, a long-time use is common. It seems certain that its abusive use, in addition to the risks of addiction, has negative effects on psychomotor capacities.

Psychological intervention seems to be effective in intervention with patients that consume benzodiazepines. This is evidenced by the smaller percentage of individuals who consume benzodiazepines after psychological intervention when compared to those who are still in psychological intervention. This supports findings regarding the benefits of psychological intervention for long-term results. Considering the expressed will by the persons who consume benzodiazepines, as well as the results, it should be an ethical imperative to inform the persons about the different alternatives with respect to prescription of these psychopharmacological drugs. Only in this way we can guarantee adequate information to the individual in order to make a conscious decision about the treatment adopted. This can be a valuable help in controlling the paradoxical effects of psychopharmacological drugs abuse, along with all personal and social consequences that result.

In short, it is essential for future practice to evaluate the impact of other interventions in order to integrate them into the basic package of health care and invest in psychological intervention. This approach could likely contribute to a reduction in health care costs, as well as for patient improvement. It would also be important replicate this research to other health centers of the country in order to confirm the guidelines recommended by these results. encaminhamento acontecia na sequência de um primeiro diagnóstico médico e da prescrição de um tratamento farmacológico prévio, pelo que seria expectável que estes utentes tivessem maior probabilidade de usar benzodiazepinas. Contudo, não deixa de ser interessante verificar que cerca de $60 \%$ dos indivíduos que já terminaram o processo de intervenção psicológica não consome benzodiazepinas, o que contrasta com os cerca de $40 \%$ que mantém o acompanhamento psicológico. Mais estudos longitudinais serão necessários para confirmar se o acompanhamento psicológico contribui de facto para a diminuição da utilização de benzodiazepinas, mas parece ser um indicador interessante que os participantes que já terminaram os seus processos de intervenção psicológica tenham quase metade da probabilidade de consumir benzodiazepinas quando comparados com aqueles que ainda estão a frequentar esse mesmo processo. Para além disso a intervenção psicológica parece promover uma redução do consumo de fármacos de uma forma geral $(17,36)$ e consequentemente parece diminuir o número de consultas com os médicos e menos gastos na saúde, tornando-se mais rentável para além de aumentar o bem-estar das pessoas (17).

Outro dado interessante obtido através deste estudo é o facto de uma boa parte dos utilizadores de benzodiazepinas manifestar vontade em beneficiar de apoio psicológico. Por um lado, estes resultados poderão evidenciar alguma insatisfação com os resultados da intervenção farmacológica isoladamente, o que estará de acordo com ideia que a farmacoterapia isoladamente terá piores resultados que quando combinada com a intervenção psicológica (37). Por outro, aponta para bons índices de motivação para iniciar um processo deste género, o que é geralmente apontado como um bom prognóstico para os resultados de uma intervenção psicológica (38). Paralelamente, este resultado servirá de indicador de que existirão claras necessidades não satisfeitas de intervenção psicológica, sendo por isso a oferta considerada reduzida (39).

As benzodiazepinas são um grupo de fármacos ansiolíticos comummente utilizados no tratamento da ansiedade e da insónia, sendo que apesar das recomendações existentes no sentido de uma utilização breve, o seu uso prolongado é frequente. Parece certo que o seu uso abusivo para além dos riscos de dependência tem efeitos negativos nas capacidades psicomotoras.

A intervenção psicológica parece ser efetiva na intervenção com doentes que utilizam benzodiazepinas, como evidencia a menor percentagem de indivíduos que consome benzodiazepinas depois de terminar os seus processos de intervenção psicológica, do que aqueles que ainda estão num processo ativo, o que vem de encontro aos dados já existentes que referem melho- 


\section{Conflict of interests}

The author declares that there is no personal or financial relationship that can be understood as presenting a potential conflict of interest. res resultados a longo prazo da intervenção psicológica. Considerando a vontade manifestada pelas pessoas que consomem benzodiazepinas, bem como os resultados existentes, deverá constituir-se como um imperativo ético a informação da pessoa sobre as diferentes alternativas existentes no que diz respeito à prescrição destes psicofármacos. Só deste modo poderemos garantir uma informação adequada ao indivíduo, condição fundamental para que este possa, ajudado pelo técnico de saúde, tomar uma decisão consciente sobre o tratamento a efetuar. Isso poderá constituir uma ajuda preciosa para controlar os efeitos paradoxais que o abuso de psicofármacos implica hoje em dia, com todas as consequências pessoais e sociais que daí advêm.

Em suma, torna-se fundamental para a prática futura avaliar não só o impacto de outras intervenções no sentido de as integrar no pacote básico dos cuidados de saúde, como também investir na intervenção psicológica, com provas dadas, e que, provavelmente, poderia contribuir para um desagravamento dos custos dos cuidados de saúde, bem como para uma melhoria dos mesmos. Seria também importante alargar esta investigação a outros Centros de Saúde do País a fim de se confirmar as direções destes resultados.

\section{Conflito de interesses}

O autor declara não existir qualquer relação pessoal ou financeira que possa ser entendida como representando um potencial conflito de interesses. 


\section{References/ Referências}

1. Konopka A, Pelka-Wysiecka J, Grzywacz A, Samochowiec J. Psychosocial characteristics of benzodiazepine addicts compared to not addicted benzodiazepine users. Progress in neuro-psychopharmacology \& biological Psychiatry 2013; 10:229-235.

2. Sim MG, Khong E, Wain TD. The prescribing dilemma of benzodiazepines. Australian Family Physician 2007; 36:923-6.

3. Furtado C, Teixeira I. Utilização de benzodiazepinas em Portugal continental (1999-2003) [Use of benzodiazepines in Portugal (1999-2003)]. Acta Médica Portuguesa 2006; 19:239-246.

4. Montgomery SA. Ansiedade e Depressão [Anxiety and Depression]. Lisboa: Climepsi; 1993.

5. Mugunthan K, McGuire T, Glasziou P. Minimal interventions to decrease long.-term use of benzodiazepines in primary care: a systemic review and metaanalysis. British Journal of General Practice 2011; 61:573-8.

6. O`Connor KP, Bélanger L, Lecomte Y. Benzodiazépines: santé mentale et santé sociale [Benzodiazepines: mental health and social health]. Santé Mentale au Québec 2003; 28:15-2. doi:10.7202/008614ar.

7. Schwaartz T, Nihalani N, Simionescu M, Hopkins G. History repeats itself: pharmacodynamic trends in the treatment of anxiety disorders. Current Pharmaceutical Design 2005; 11:255-63.

8. Anthierens S, Habraken H, Petrovic M, Christiaens T. The lesser evil? Initiating a benzodiazepine prescription in general practice: a qualitative study on GPs` perspectives. Scandinavian Journal of Primary Health Care 2007; 25:214-9.

9. World Health Organization. The World Health Report 2008: Primary Health Care Now More Than Ever. 2008. in: URL: http://www.who.int/whr/2008/ whr08 pr.pdf

10. Coutinho D, Vieira ND, Teixeira MH. Condução sob influência de benzodiazepinas e antidepressivos: prescrição médica e abuso [Driving under the influence of benzodiazepines and antidepressants: medical prescription and abuse]. Acta Médica Portuguesa 2011; 24:431-438.

11. Infarmed. Psicofármacos: evolução do consumo em Portugal Continental (2000-2012) [Psychopharmaceuticals: evolution of consumption in Portugal (2000-2012)]. 2013. in: URL: http://www.infarmed.pt/documents/15786/17838/psicofarmacos_relatorio2013+\%281\%29.pdf/3e52568f-7f90-47c89903-d128395c73e5

12. Direção-Geral da Saúde. Portugal: saúde mental em números [Portugal: mental health in numbers]. 2014. in: URL: https://www.dgs.pt/estatisticas-desaude/estatisticas-de-saude/publicacoes/portugal-saude-mental-em-numeros-2014.aspx

13. Organisation for Economic Co-operation and Development. Health Care Systems: Efficency \& Policy Settings. 2010. in: URL: http://www.oecd.org/eco/ healthcaresystemsefficiencyandpolicysettings.htm

14. Câmara H, Rocha C, Balteiro J. Grau de conhecimento e consumo de psicofármacos dos alunos da Escola Superior de Tecnologia da Saúde de Coimbra [Degree of knowledge and consumption of psychopharmaceuticals of the students of the School of Health Technology of Coimbra]. Revista Portuguesa de Saúde Pública 2011, 29:173-179.

15. Ordem dos Psicólogos Portugueses. Evidência científica sobre custo-efectividade de Intervenções psicológicas em cuidados de saúde primários [Scientific evidence about cost-effectiveness of psychological interventions in primary health care]. 2011. in: URL: https://www.ordemdospsicologos.pt/ficheiros/ documentos/1 evidaancia cientaifica sobre custo efectividade de intervena aoes psicolaogicas em cuidados de saaode.pdf

16. Harkness E, Bower P. On-site mental health workers delivering psychological therapy and psychosocial interventions to patients in primary care: effects on the professional practice of primary care providers (Review). The Cochrane Collaboration 2010; 7:3-13.

17. Layard R, Clark D, Knapp M, Mayraz G. Cost-benefit analysis of psychological therapy. Centre for Economic Performance 2007; 829:3-8.

18. Almeida L, Freire T. Metodologia da investigação em Psicologia e Educação [Methodology of research in Psychology and Education]. 5a ed. Braga: Psiquilibrios Edições; 2008.

19. Hallstrom C, McClure N. Ansiedade e Depressão: perguntas e respostas [Anxiety and Depression: questions and answers]. Lisboa: Climepsi; 2000.

20. Gourion D. Les traitements médicamenteux des troubles anxieux [Drug treatments for anxiety disorders]. Annales Médico Psychologiques 2003; 161:255-259.

21. Voshaar R, Gorgels W, Mol A, Balkom A, Van De Lisdonk E, Breteler M, Van Den Hoogen H, Zitman F. Tapering off long-term benzodiazepine use with or without group cognitive-behavioural therapy: three-condition, randomized controlled trial. British Journal of Psychiatry 2003; 182:498-504.

22. Paprocki J. O emprego de ansiolíticos benzodiazepínicos pelo clínico geral e por especialistas não psiquiatras [The prescription of benzodiazepine anxiolytics by the general practitioner and non-psychiatric specialists]. Revista ABP-APAL 1990; 64:305-12.

23. Zandstra SM, Führer JW, Van de Lisdonk EH, et al. Different study criteria affect the prevalence of benzodiazepine use. Social Psychiatry and Psychiatric Epidemiology 2002; 37:139-144.

24. Ashton $\mathrm{H}$. The diagnosis and management of benzodiazepine dependence. Addictive disorders $2005 ; 18: 249-255$.

25. Ford N, Ludbrook G, Galletly C. Benzodiazepines may reduce the effectiveness of ketamine in the treatment of depression. Australian \& New Zealand Journal of Psychiatry 2015; 49:1227-1239. doi:10.1177/0004867415590631.

26. Galleguillos T, Risco L, Garay JL, González M, Vogel M. Tendencia del uso de benzodiazepinas en una muestra de consultantes en atención primaria [Tendency of the use of benzodiazepines in a sample of health primary care patients]. Rev Méd Chile 2003; 131:535-40.

27. Sirdifield C, Anthierens S, Creupelandt H, Chipchase S, Christiaens T, Siriwardena A. general practitioners` experiences and perceptions of benzodiazepine prescribing: systematic review and meta-synthesis. BMC Family Practice 2013; 14:1-13.

28. Isacson D, Carsjo, Bergman U, Blackburn JL. Long-term use, mortality and migration among benzodiazepine users in a Swedish community: An eightyear follow-up. Journal of Clinical Epidemiology 1992; 45:429-36.

29. Ballard C, Gauthier S, Corbett A, Brayne C, Aarsland D, Jones E. Alzheimer`s disease. Lancet 2011; 377:1019-31. doi: 10.1016/S0140-6736(10)61349-9.

30. Li J, Wang Y, Zhang M, Xu Z, Gao C, Fang C, et al. (2011). Vascular risk factors promote conversion from mild cognitive impairment to Alzheimer disease. Neurology 2011; 76:1485-91.

31. Morin C, Bastien C, Guay B, Radouco-Thomas M, Leblanc J, Valliéres A. Randomized Clinical Trial of Supervised Tapering and Cognitive Behavior Therapy to Facilitate Benzodiazepine Discontinuation in Older Adults with Chronic Insonmia. The American Journal of Psychiatry 2004; 161:332-342.

32. Lagnaoui R, Depont F, Fourrier A, Abouelfath A, Begaud B, Verdoux H, Moore N. Patterns and correlates of benzodiazepine use in the French general population. European Journal of Clinical Pharmacology 2004; 60:523-29.

33. Jann M, Kennedy W, Lopez G. Benzodiazepines: A Major Component in Unintentional Prescription Drug Overdoses with Opioid Analgesics. Journal of Pharmacy Practice 2014; 27:4-16. doi: 10.1177/0897190013515001.

34. Heuzenroeder L, Donnelly M, Haby MM, Mihalopoulos C, Rossell R, Carter R, Andrews G, Vos T. Cost-effectiveness of psychological and pharmacological interventions for generalized anxiety disorder and panic disorder. Australian and New Zealand Journal of Psychiatry 2004; 38:602-12.

35. Ricou M, Marinho P, Canário C, Sampaio I, Regalado J, Duarte I. Predictors of the success of the psychological intervention in S. João's health center. The Spanish Journal of Psychology 2017. Submetido para publicação.

36. Sava F, Yates B, Lupu V, Szentagotai A, David D. Cost-effectiveness and cost-utility of cognitive therapy, rational emotive behavioral therapy, and fluoxetine (prozac) in treating depression: A randomized clinical trial. Journal of Clinical Psychology 2009; 65:36-52. 
37. Hunsley J, Elliot K, Therrien Z. The Efficacy and Effectiveness of Psychological Treatments. The canadian Psychological Assotiation 2013. in: http:// www.cpa.ca/docs/File/Practice/TheEfficacyAndEffectivenessOfPsychologicalTreatments_web.pdf

38. Ryan R, Lynch M, Vansteenkiste M, Deci E. Motivation and Autonomy in Counseling, Psychotherapy, and Behavior Change: A Look at Theory and Practice. The Counseling Psychologist 2011; 39:193-260. doi 10.1177/0011000009359313.

39. Hespanhol A, Veiga G, Ricou M. Consulta de psicologia clínica no Centro de Saúde S. João: assegurar qualidade na perspectiva de gestão [Clinical psychology consultation at S. João health center: ensuring quality in the management perspective]. Revista Portuguesa de Psicossomática 2005; 7:59-64. 